Linguagem em (Dis)curso - LemD, v. 8, n. 1, p. 149-174, jan./abr. 2008

\title{
CONSIDERAÇÕES SOBRE A CENA ENUNCIATIVA: A CONSTRUÇÃO DO ETHOS NOS BLOGS
}

\author{
Palmira Bahia Heine*
}

\begin{abstract}
Resumo: $\mathrm{O}$ artigo ora apresentado pretende tecer algumas considerações acerca da construção do ethos em blogs, na internet, tendo como ponto de partida a análise de dois blogs de adolescentes: Camila e Joana (de 16 e 14 anos). São considerados aqui os pressupostos teóricos da Análise do Discurso, bem como a concepção de ethos postulada por Maingueneau (2005b). Objetiva-se, no artigo, estabelecer uma discussão acerca do modo como o ethos é construído num veículo público (a internet), dentro de um gênero discursivo de caráter intimista (o blog), a partir da focalização de especificidades e características do ethos nesse gênero.

Palavras-chave: ethos; blog; internet; discurso; adolescente.
\end{abstract}

\section{INTRODUÇÃO}

O blog é um dos gêneros digitais que apareceram com o advento do hipertexto. Como tal, carrega características inerentes ao ambiente hipertextual e outras inerentes à sua constituição específica. O blog pessoal é, ao mesmo tempo, um espaço dedicado à exposição de aspectos da vida íntima de alguém e um local que propicia a interação entre o seu escrevente e os leitores das mensagens nele contidas. Constitui-se, portanto, como um espaço discursivo situado na fronteira entre o público (caráter do hipertexto) e o privado (caráter do diário tradicional).

\footnotetext{
* Doutoranda em lingüística na Universidade Federal da Bahia. Bolsista da Fapesb. E-mail: <pheine@ig.com.br>.
} 
Considerando esse caráter público e privado do blog, este artigo apresenta uma análise relativa ao modo como o ethos é construído neste gênero. Dois blogs de adolescentes foram tomados como objeto da análise, a saber: o de Camila (16 anos) e o de Joana (14 anos).

$\mathrm{Na}$ seqüência, apresenta-se: uma breve revisão da literatura sobre blog; a noção de ethos, conforme tem sido discutida na literatura; e a análise dos dois blogs.

\section{CONSIDERAÇÕES SOBRE O BLOG}

Com relação às inovações trazidas pela internet, mais especificamente com o hipertexto, destaca-se o surgimento de inúmeros gêneros discursivos, conhecidos também como gêneros digitais, dentre os quais podem-se destacar os e-mails, os chats, os blogs, os quais, na verdade, representam uma transmutação de gêneros digitais já existentes, tais como a carta, as conversas entre colegas ou amigos, os diários secretos, etc.. ${ }^{1}$ Neste artigo, no entanto, é o gênero blog que será tomado como objeto de análise, pois é a partir de blogs retirados da internet que se observará o modo de construção do ethos num gênero que se constitui entre o público e o privado.

Consoante Oliveira (2002, p. 121), na década de 90 do século XX, época em que a internet começa a se popularizar como instrumento de pesquisa e comunicação, surge um fenômeno conhecido como "a primeira onda da web escriturável", na qual as pessoas poderiam, através de ferramentas simples, postar diários online. Nessa época, porém, as ferramentas utilizadas para a construção de páginas pessoais não eram muito sofisticadas e não possibilitavam o armazenamento de inúmeras imagens e nem a rapidez de atualização, se comparadas às ferramentas dos dias atuais. Nesse período, poucas pessoas utilizavam a internet e o número de diários virtuais era muito pequeno.

\footnotetext{
${ }^{1}$ Segundo Marcuschi (2001), o termo 'hipertexto' foi cunhado por Theodor Nelson em 1964 e foi criado para se referir a um tipo de escrita não-linear e não-seqüencial, que confere ao leitor a possibilidade de realizar a escolha de caminhos a serem seguidos na leitura do texto.
}

HEINE - Considerações sobre a cena... 
Já a "segunda onda da web escriturável" trouxe uma grande popularização da internet, pois permitiu a democratização de acesso e aumentou a velocidade na publicação virtual de páginas pessoais, o envio de e-mails, dentre outras possibilidades. Esse período se iniciou por volta do ano de 1999 e possibilitou um aumento significativo do número de pessoas que postavam diários virtuais. Nessa época, surgiram softwares gratuitos que permitiam que qualquer pessoa (mesmo aquela que não conhecesse a linguagem $\mathrm{HTML}^{2}$ ) pudesse construir páginas pessoais e atualizá-las constantemente. O primeiro software gratuito foi criado pela empresa norte-americana Pitas, que deu lugar posteriormente a outros softwares tais como o Blogger, que se popularizou e tornou-se a base para a construção de páginas pessoais na internet. A partir de ferramentas como essa, qualquer um pode criar e postar virtualmente uma página pessoal, atualizando-a se julgar necessário. $\mathrm{O}$ termo $\log ^{3}$ deriva da expressão inglesa Weblog, cujo significado atual é algo como "diário da web".

Komesu (2005, p. 99) chama a atenção para a estrutura textual dos blogs, composta por parágrafos curtos e pela publicação das mensagens em ordem cronológica. A referida pesquisadora define blog da seguinte maneira:

O blog pode ser definido [...] como uma página web, composta de parágrafos dispostos em ordem cronológica (dos mais aos menos atuais, colocados em circulação na rede), atualizada com frequência pelo usuário. $\mathrm{O}$ dispositivo permite a qualquer usuário a produção de textos verbais (escritos) e não-verbais (com fotos, desenhos, animações, arquivos de som), a ação de copiar e colar um link e sua publicação na web, de maneira rápida e eficaz, às vezes praticamente simultânea ao acontecimento que se pretende narrar.

A organização textual dos blogs é marcada por inúmeros posts escritos pelos blogueiros ${ }^{4}$ e organizados de forma cronológica. Os escreventes de blogs podem, em questão de minutos, postar mensagens

\footnotetext{
${ }^{2}$ HTML é uma sigla do termo HyperText Markup Language; é uma das linguagens utilizadas para desenvolver páginas na Internet; existem outras linguagens mais avançadas, porém, a maioria dos sites funciona em linguagem HTML.

3 O acesso aos blogs é livre e não é necessário ter autorização prévia para consultá-lo, podendo, portanto, qualquer internauta ter acesso a um blog.

${ }^{4} \mathrm{O}$ termo 'blogueiro' é utilizado para referir-se ao internauta que possui um blog e que o utiliza com freqüência.
} 


\section{2}

de diferentes conteúdos. Pode-se afirmar que existem atualmente diversos tipos de blogs que possuem propósitos comunicativos diferentes.

Assim, há os blogs políticos que objetivam discutir questões relacionadas à política, além de proporcionarem um espaço interativo entre os internautas e os candidatos; os jornalísticos, nos quais são veiculadas notícias e reportagens de maneira independente, sem a censura das grandes empresas jornalísticas; os blogs educativos, destinados a propiciar um espaço para a construção do conhecimento e veiculação de conteúdos e textos ligados às diferentes disciplinas abordadas em sala de aula; os fotologs (ou flogs) que são espécies de álbum no qual são postadas fotos digitais acompanhadas de legendas, e os blogs pessoais, espaços digitais nos quais os escreventes falam sobre seu dia-a-dia, suas intimidades etc., sendo estes últimos objeto de análise deste artigo.

Consoante Sibilia (2003), o fenômeno de revelações da intimidade na internet se faz presente principalmente nos blogs pessoais, que, segundo a autora, podem ser definidos como "diários pessoais publicados na internet, uma modalidade de "escrita íntima" ou de narração auto-referente, conhecida como weblogs ou, simplesmente, blogs". Segundo ela, os blogs pessoais atendem a uma necessidade muito presente na sociedade pós-moderna: a visibilidade. A autora defende a idéia de que os blogs representam um processo de escancaramento da intimidade em um espaço público. Isso pode ser visto no trecho a seguir:

O fato dos novos diários íntimos serem publicados na internet, não é um detalhe menor, pois o principal objetivo de tais estilizações do eu parece ser, precisamente, a visibilidade - em perfeita sintonia, aliás, com outros fenômenos contemporâneos que se propõem a escancarar a minúcia mais "privada" de todas as vidas ou de uma vida qualquer: dos reality-show decalcados no modelo Big Brother às revistas no estilo Caras, dos programas de TV que se inscrevem na linhagem do Ratinho livre à proliferação de documentários em primeira pessoa, do sucesso editorial das biografias à crescente importância da imagem nos políticos e em outras figuras públicas, etc. (SIBILIA, 2003 - Retirado do site: http://www.facom.ufba.br/ciberpesquisa/tics/2003/body_sibilia _2003.htm. Acesso em 02/08/2005)

HEINE - Considerações sobre a cena... 
Para Oliveira (2002), os blogs pessoais representam um espaço destinado ao discurso intimista e confessional e, por isso, são muito semelhantes aos diários escritos e secretos ainda utilizados por algumas adolescentes. A referida autora ressalta o fato de que os blogs inicialmente serviam apenas como filtro de notícias, não sendo, portanto, nessa época, um espaço de revelação da intimidade. No entanto, rapidamente os blogs como filtro de notícias deram origem aos blogs pessoais. Seu formato textual, marcado pela postagem de mensagens datadas e organizadas em ordem cronológica, cumpria a função de um verdadeiro diário postado na rede.

Assim, Oliveira (2002, p. 144) afirma:

Em pouco tempo os diários virtuais no formato blog evoluíram de filtro de notícias para um conceito mais diretamente ligado aos tradicionais diários íntimos, antes trancados a sete chaves. De fato muitos deles são utilizados como lugar exclusivo onde o blogueiro conta o dia-a-dia, faz confissões, desabafos, bem aos moldes do diarismo tradicional.

Komesu (2005, p. 198) argumenta que o blog representa um modo de enunciação baseado no que ela chama de "publicização de si": o objetivo principal do enunciador é ser visto. Segundo a pesquisadora (2005, p. 198), o blog instaura "um modo de enunciação fundado na publicização de si na relação com a intimidade construída entre enunciador e co-enunciador".

Após tecer essas considerações, cabe perguntar: de que modo o co-enunciador pode interferir no discurso do enunciador, marcando-o e restringindo-o? Neste artigo pretende-se defender, através da explicação de ethos de Maingueneau ${ }^{5}$ (2005b), a idéia de que a intimidade revelada nos blogs é uma intimidade restrita, moldada às expectativas dos co-

${ }^{5}$ Optou-se pelo esquema de Maingueneau (2005b) pelo fato de este possibilitar a compreensão da forma de construção do ethos em textos escritos que não possuem necessariamente um teor argumentativo, extrapolando o quadro da argumentação retórica. Segundo Maingueneau (2005b, p. 69) a noção de ethos pertence à tradição retórica, no entanto ele propõe inscrever esta noção em um quadro diferente: o da análise do discurso. Segundo o referido autor (2005b, p.69), a noção de ethos em Análise do discurso "muitas vezes freqüenta os mesmos corpora e encontra as mesmas problemáticas que os especialistas da argumentação, mas o faz com interesses distintos." No entanto, na $\mathrm{AD}$ a noção de ethos caminha em direções que ultrapassam o quadro da argumentação: em particular estudando sua incidência em textos escritos e em textos que não apresentam nenhuma seqüencialidade do tipo argumentativo". 


\section{4}

enunciadores, e dirigida muitas vezes por imagens pré-discursivas feitas por eles, baseadas em estereótipos comuns e partilhados por enunciadores e co-enunciadores.

Quanto à estrutura, pode-se afirmar que os blogs pessoais caracterizam-se pela postagem de mensagens geralmente destinadas a um determinado grupo de pessoas conhecidas (os co-enunciadores). As mensagens, também chamadas de posts pelos blogueiros, são organizadas cronologicamente. Ao final de cada um dos posts, há um link que possibilita ao leitor comentá-lo, interagindo assim com o escrevente do blog.

Na maioria dos blogs pessoais, há um espaço destinado à postagem de links para os blogs de amigos, colegas e conhecidos, formando uma grande rede intertextual.

A escrita dos blogs aproxima-se do tom coloquial e não segue as regras da norma culta. No caso dos blogs de adolescentes, é comum encontrarem-se gírias, abreviaturas e a mistura entre letras em caixa alta e caixa baixa, caracterizando um tipo de escrita muito próprio dos adolescentes internautas escreventes de blogs. Muitas vezes encontrar-seá, nos blogs, tendência para uma escrita fonética, em que as palavras estarão grafadas de maneira muito próxima ao modo como se fala. Assim, como exemplo, há palavras como 'não', que nos blogs é escrita como naum, e tão, como taum etc.

Feitas considerações sobre a constituição e características dos blogs, cabe agora trazer à tona o conceito de ethos, uma vez que este artigo objetiva evidenciar como ele se constitui dentro do discurso intimista dos blogs na internet.

\section{CONSIDERAÇÕES SOBRE O ETHOS}

\subsection{O ethos na antigüidade}

Todo discurso pressupõe a construção de uma imagem daqueles que estão envolvidos no processo interativo. Segundo Amossy (2005a, p. 
9), "Para construir tal imagem, não é necessário que o enunciador ${ }^{6}$ fale sobre si ou apresente para os ouvintes suas características, suas qualidades e defeitos, pois, no momento do discurso, lançam-se pistas acerca desta imagem: seu estilo, sua visão de mundo, seu conhecimento acerca de determinados assuntos, dentre outros, que permitirão aos ouvintes realizarem a construção da imagem do enunciador.

Dentro do arcabouço teórico da Análise do Discurso, a terminologia ethos diz respeito à construção de uma imagem de si através do discurso. Assim, dizer que os participantes do discurso criam uma auto-imagem através dele, significa também afirmar que o discurso carrega as marcas do enunciador e do co-enunciador, entendidos aqui como aqueles que interagem no processo discursivo. As imagens do enunciador e do co-enunciador agem no campo discursivo, de modo a serem parte constituinte do processo enunciativo. À construção dessa imagem de si no discurso convencionou-se chamar de ethos.

Para discorrer sobre o ethos é imprescindível retomar a tradição antiga, proveniente da Grécia, focalizando principalmente a teoria de Aristóteles, que foi o responsável por sistematizar a Retórica como a arte da persuasão. Foi com Aristóteles ${ }^{7}$ que o conceito de ethos foi colocado como ponto fundamental para o exercício de persuasão. Segundo ele, há três espécies de provas empregadas pelo orador para persuadir seu auditório, quais sejam: o caráter do orador (o que ele chamou de ethos); as

6 O termo 'enunciado' é utilizado por Maingueneau (2001) com o valor de frase inscrita num contexto particular. Enunciador, na perspectiva do autor, seria aquele a quem se outorga no discurso uma posição institucional que marca sua relação com o saber. $\mathrm{O}$ co-enunciador, portanto, seria aquele a quem o enunciador dirige o seu discurso, que não é entendido como uma figura dotada de passividade, mas que exerce um papel ativo no processo discursivo. O termo coenunciador foi introduzido na lingǘstica enunciativa por Culioli, como um termo correlativo ao de enunciador, acentuando a idéia de que a enunciação é um processo no qual dois participantes desempenham um papel ativo, pois numa enunciação há uma alternância do papel de ouvinte e locutor, fazendo com que ambos participem de forma dinâmica do processo enunciativo. Enquanto a Análise do Discurso utiliza as terminologias enunciador e co-enunciador, a Retórica fala em locutor e receptor. Segundo os estudos retóricos, o locutor designa a pessoa que fala, aquela que emite uma mensagem no ato da comunicação efetiva. Consoante Charaudeau e Maingueneau (2004, p. 311), o locutor é o sujeito falante responsável pelo ato de linguagem e, portanto, exterior a este. Opõe-se, nessa mesma relação de exterioridade, ao sujeito que acolhe o ato de linguagem, que pode ser designado nos termos de interlocutor, receptor ou alocutário. Portanto, para os estudos retóricos, utiliza-se a terminologia 'orador' como sinônimo de terminologia 'locutor', e 'auditório' como sinônimo de 'receptor'.

7 A obra Retórica, de Aristóteles, traduzida no Brasil em 1998, traz o debate sobre ethos, pathos e lógos. 
paixões despertadas nos ouvintes (o páthos), e o próprio discurso (o lógos). Assim, o ouvinte se deixa convencer pelas três provas. O páthos é, em Aristóteles, a representação dos sentimentos do próprio auditório. Para convencê-lo é preciso impressionar, seduzir, fundamentar os argumentos na paixão, para que se possa aumentar o poder de persuasão. Dessa forma, o páthos liga-se ao ouvinte, sobre o qual recai a carga afetiva gerada pelo lógos do orador. Este último, por sua vez, sendo o discurso, convence, por si mesmo, pelos argumentos utilizados em situação de comunicação concreta. O lógos pode ser ornamental, literário, argumentativo etc. $\mathrm{O}$ tipo de argumento dependerá da situação comunicativa concreta na qual se insere o orador. Consoante Meyer (1994, p. 43):

O orador é simbolizado pelo ethos: a sua credibilidade assenta no seu caráter, na sua honorabilidade, na sua virtude, em suma, na confiança que nele se deposita. O auditório é representado pelo páthos: para convencê-lo é preciso impressioná-lo [...] Resta, enfim, a terceira componente, sem dúvida, mais objetiva: o lógos, o discurso.

O ethos, portanto, estaria ligado ao orador, ao seu caráter, à sua virtude, na confiança que ele pode gerar no auditório. O caráter (ou ethos) do orador constituirá ponto importante na persuasão, pois, segundo Aristóteles (1998, p. 49):

Persuade-se pelo caráter quando o discurso é proferido de tal maneira que deixa a impressão de o orador ser digno de fé. Pois acreditamos mais e bem mais depressa em pessoas honestas, em todas as coisas em geral, mas sobretudo nas de que não há conhecimento exacto e que deixam margem para dúvida

Dessa forma, Aristóteles argumenta que a confiança do auditório no orador reveste-se de maior importância "sobre aquelas coisas em que não há possibilidade de se ter certeza e que deixam lugar a dúvidas" (ROHDEN, 1997, p. 90).

$\mathrm{O}$ ethos aristotélico não pode ser compreendido isoladamente do páthos e do lógos no processo retórico; no entanto, Aristóteles afirma que o ethos constitui praticamente a mais importante das provas. Meyer (1994, p. 49-50) afirma, então: "Páthos, lógos e ethos encontram-se sem que possamos nunca delimitá-los com precisão. A autojustificação implica

HEINE - Considerações sobre a cena... 
argumentos (lógos) mas também o ter em conta o outro (páthos) a quem se quer agradar para ser aceito ou a quem se quer manipular (ethos)".

Assim, na concepção aristotélica, o ethos será o caráter do orador representado através do discurso, caráter esse que desempenhará um importante papel na persuasão. O ethos, para Aristóteles, pode ser compreendido como a imagem de si que o orador cria através do discurso (o ethos se faz no âmbito do discurso) e não equivale necessariamente ao caráter real do orador.

\subsection{O ethos em Maingueneau}

A Análise do Discurso, tendo como principal expoente nos estudos do ethos Maingueneau (1997, 2001, 2005a, 2005b, 2006), vai retomar o conceito aristotélico de ethos quando afirma que este é a imagem de si no discurso. No entanto, a Análise do Discurso vai além dos estudos elaborados pela Retórica, pois pretende analisar as imagens criadas pelos enunciadores no discurso baseando-se não apenas em situações de eloqüência judiciária ou em enunciados orais, mas se estendendo a todo e qualquer discurso, mesmo àqueles presentes no texto escrito.

A noção de ethos, para ele, permite refletir sobre o processo mais geral da adesão dos sujeitos a uma certa posição discursiva. Retomando a idéia aristotélica de que o ethos é construído na instância do discurso, Maingueneau (2005a, 2005b) afirma que não existe um ethos preestabelecido, mas sim um ethos construído no âmbito da atividade discursiva. Assim, a imagem de si é um fenômeno que se constrói dentro da instância enunciativa, no momento em que o enunciador toma a palavra e se mostra através do seu discurso. Barthes (apud MAINGUENEAU, 2005a, p. 70) define, então, o ethos da seguinte maneira: "São os traços de caráter que o orador deve mostrar ao auditório (pouco importando sua sinceridade) para causar boa impressão: são os ares que assume ao se apresentar [...]. O orador enuncia uma informação e ao mesmo tempo diz: eu sou isso e não aquilo".

Assim, diz-se que o ethos liga-se ao orador, através principalmente das escolhas lingüísticas feitas por ele, escolhas estas que revelam pistas 


\section{8}

acerca da imagem do próprio orador, continuamente construída no âmbito discursivo.

Ao sistematizar o conceito de ethos para a Análise do Discurso, Maingueneau (1997, 2001, 2005a, 2005b, 2006) afirma que este se liga diretamente ao tom que engendra o discurso. Esse tom, por sua vez, estaria ligado a uma corporalidade e ao caráter do enunciador. Segundo Maingueneau (1997, p. 46), "a Retórica antiga organizava-se em torno da palavra viva e integrava, conseqüentemente, à sua reflexão, o aspecto físico do orador, seus gestos, bem como sua entonação”. Nos textos escritos não há a representação direta dos aspectos físicos do orador, mas há pistas que indicam e levam o co-enunciador a atribuir uma corporalidade e um caráter ao enunciador, categorias essas que interagem no campo discursivo. Para o referido autor, o caráter seria "o conjunto de traços psicológicos que o leitor-ouvinte atribui espontaneamente à figura do enunciador, em função de seu modo de dizer" (MAINGUENEAU, 1997, p. 47), enquanto que a corporalidade remeteria a "uma representação do corpo do enunciador, construído no processo discursivo".

Assim, pode-se dizer que o ethos relaciona-se com a construção de uma corporalidade do enunciador por intermédio de um tom lançado por ele no âmbito discursivo. O tom permitirá ao leitor construir, no texto escrito, uma representação subjetiva do corpo do enunciador, corpo este manifestado não fisicamente, mas construído no âmbito da representação subjetiva. A imagem corporal do enunciador faz emergir a figura do fiador, entendida aqui como aquela que deriva da representação do corpo do enunciador efetivo, se construindo no âmbito do discurso. O fiador é aquele que se revela no discurso e não corresponde necessariamente ao enunciador efetivo.

Portanto, no âmbito discursivo, pode-se criar a imagem de um fiador calmo e tranqüilo, mesmo que o enunciador não tenha essas características. Essa construção da imagem do fiador se relacionará, portanto, com as escolhas lexicais feitas pelo enunciador, que conferirão ao enunciado um tom de calma e tranqüilidade, fazendo emergir, portanto, a imagem de um fiador calmo e tranqüilo. O fiador, para Maingueneau (2005a; 2005b), é uma imagem construída pelo coenunciador com base em indícios textuais de diversas ordens. 


\section{ANÁLISE DE DADOS}

A análise do ethos aqui apresentada tem como objeto dois blogs de adolescentes (Camila, 16 anos; e Joana, 14 anos), ambos extraídos do corpus de minha pesquisa de mestrado (HEINE, 2007). Foram aqui focalizados alguns aspectos que seriam mais reveladores da construção do ethos em blogs. O exemplo 1, para começar, traz um trecho da apresentação do blog da Camila.

Exemplo 1:

BLOG DA CAMILA:

Meu noMe é Camila nick CaCaZiNha ou cAcA, eU teNho 16 aNoS e apago veLiNhas no dia 21/01, poRtanto soU AquaRiaNa! teNhu gêniO foRTe, soU coMpLicaDa e ChoRoNa! eU aMo meuS aMigoS, miNha família, boRboLeTaS, fLoReS, caRtaS, cHoCoLaTe, MeU ceL, fiCaR oLhanDu u maR, peNsaR coiSaS iNúteiS, RiR, pRaia, SaiR, teLefoNe, neRdiaR, ChoRaR, RoSa ... eU nãO goSto de faLsiDaDe e sóH! aMiZaDe pRa miM éH tuDo.. keM nauM teM uM aMigo nauM tem naDa! (Retirado de: http://www.cacazuda.weblogger.terra.com.br/ index.htm)

No trecho do exemplo 1, aparece a imagem de uma fiadora sensível, com a qual as leitoras adolescentes podem se identificar. O tom romântico e sonhador revela-se principalmente pela escolha de determinadas expressões, tais como: "eu amo meus amigos, minha família, borboletas, ou ainda, ficar olhando o mar", entre outras.

Assim, a utilização de determinadas palavras em lugar de outras, o uso de diminutivos, aumentativos etc. ou de certas expressões, como as exemplificadas anteriormente, pode indicar determinado tom a depender da forma como o enunciador se apropria da língua. No caso do enunciado destacado em negrito no exemplo (1), por exemplo, fica patente a carga emotiva, fazendo com que o tom da enunciação seja concebido como um tom romântico.

No exemplo (1), associa-se a imagem da adolescente que escreveu esse blog à de uma adolescente emotiva, revelando-se um ethos doce, lúdico. Esta imagem reveste-se de uma corporalidade na qual uma 
adolescente doce, frágil, é encenada, apoiando-se sobre um conjunto de representações sociais que se constroem sobre a idéia de que as adolescentes de dezesseis anos estão em busca do amor, de um "príncipe encantado", como num sonho, e, por isso, são românticas e frágeis.

Maingueneau (2005b) estabelece uma importante diferenciação entre o ethos dito e o mostrado. O ethos dito é aquele através do qual o enunciador mostra diretamente suas características, dizendo ser essa ou aquela pessoa, ao passo que o ethos mostrado é aquele que não é dito diretamente pelo enunciador, mas é reconstituído através de pistas fornecidas por ele no seu discurso. Maingueneau (2005b, p.71) ainda observa: "se o ethos está crucialmente ligado ao ato de enunciação, não se pode negar, no entanto, que o público constrói representações do ethos antes mesmo que ele (o enunciador) fale". Assim, faz-se uma distinção entre o ethos pré-discursivo e o ethos discursivo. $\mathrm{O}$ ethos pré-discursivo seria, portanto, a imagem que o co-enunciador faz do enunciador, antes mesmo que este último tome a palavra para si. O esquema de Maingueneau (2005b), que pode ser visualizado na figura 1, permite uma melhor compreensão dessa relação.

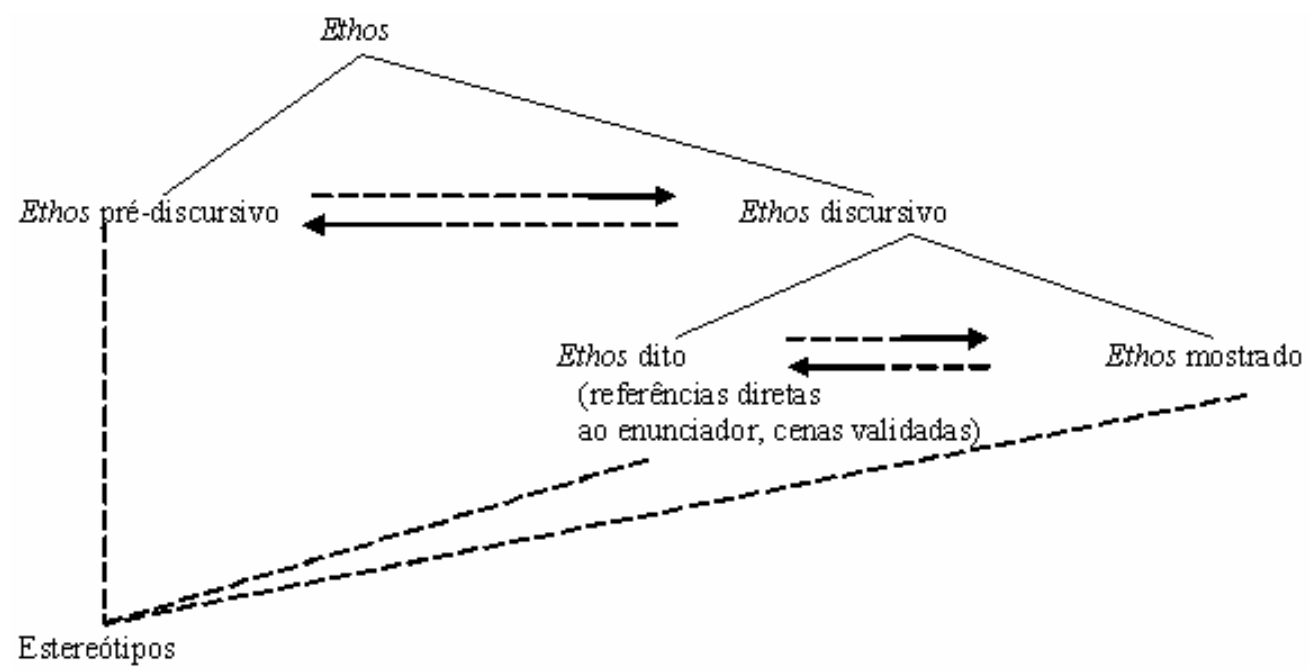

Figura 1 - Processos discursivos do ethos (MAINGUENEAU, 2005b).

Segundo o esquema proposto, o ethos compõe-se de duas partes: o ethos pré-discursivo e o ethos discursivo. Essas duas categorias relacionam- 
se mutuamente a partir do momento em que o ethos pré-discursivo pode ou não ser confirmado pelo ethos discursivo, ou ainda quando o ethos discursivo pode reformular a imagem inicial formada pelo ethos prédiscursivo, confirmado ou refutado.

O ethos discursivo, por sua vez, engloba as noções de ethos dito e ethos mostrado. O ethos dito seria aquele criado através das referências diretas ao enunciador, enquanto o ethos mostrado estaria no domínio do não explícito, da imagem que não está diretamente representada no texto, mas que pode ser construída através de pistas seguidas pelo coenunciador. $\mathrm{O}$ ethos dito e o ethos mostrado, assim como sugerido no esquema, relacionam-se mutuamente, já que não há uma linha clara de separação entre o explicitado e o não explicitado.

$\mathrm{Na}$ base do esquema, estão os estereótipos, através dos quais o coenunciador utiliza-se de representações culturais fixas, de modelos préconstruídos para atribuir algumas características e não outras ao enunciador.

Para exemplificar melhor as questões abordadas até aqui, lança-se mão de um trecho da página inicial do blog da Camila (ver exemplo 2).

\section{Exemplo 2:}

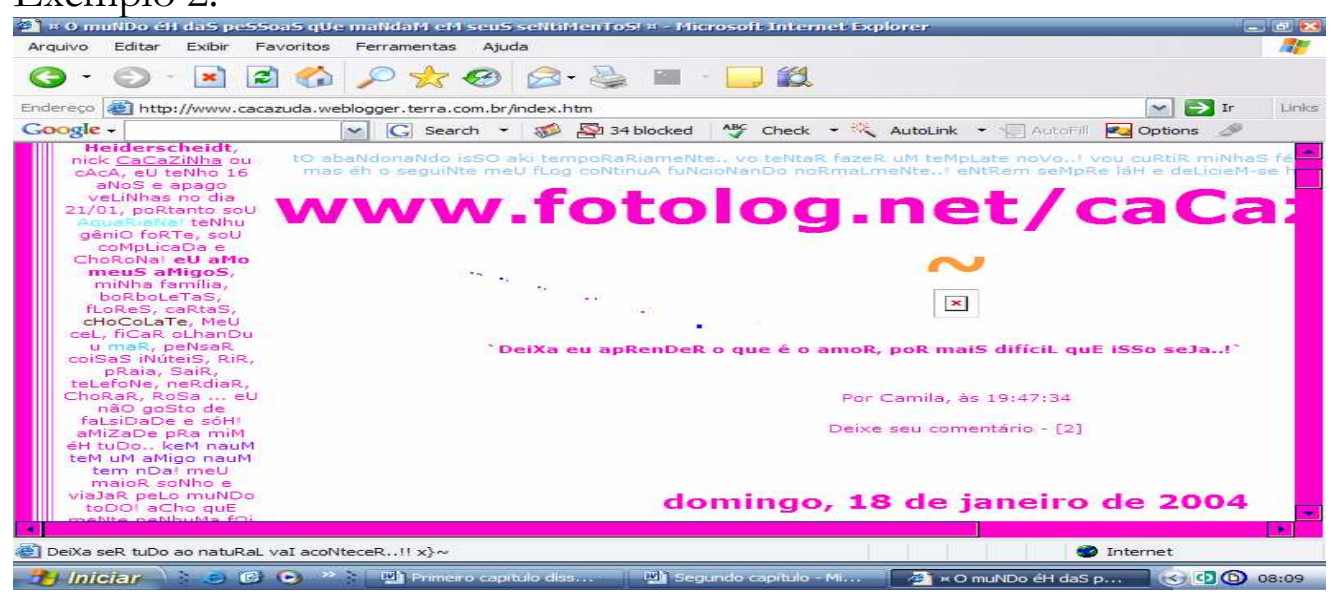

(Retirado de: http://www.cacazuda.weblogger.terra.com.br/index.htm)

No caso do exemplo 2, há o uso das cores rosa e azul, indicando de antemão uma atmosfera leve e doce, que vem a ser confirmada pelo discurso da enunciadora. Ao mesmo tempo, a frase de chamada presente 


\section{2}

no blog, "deixa eu aprender o que é o amor, por mais difícil que isso seja", fornece pistas acerca da imagem de uma fiadora sensível ao amor que nele se constitui. Essa imagem, por sua vez, baseia-se em noções estereotipadas do romântico. Ser romântico, portanto, é ser emotivo, fantasioso, devaneador, segundo as características pré-atribuídas culturalmente. As cores rosa e azul contribuem para a confirmação do estereótipo inicial do ethos. Assim, o ethos pré-discursivo, construído através das pistas citadas anteriormente, coincide com o ethos discursivo, mostrado no momento do discurso pela escrevente do blog: o de uma adolescente que busca compreender "o que é o amor".

Consoante Maingueneau (2005b), o ethos é parte constitutiva da cena de enunciação. Esta pressupõe três diferentes instâncias: a cena englobante, definida por Maingueneau (2005b) como correspondente ao tipo de discurso, o qual, segundo ele, diz respeito aos discursos associados aos diversos setores de atividade social; a cena genérica, que se associa a um determinado gênero do discurso, e finalmente a cenografia, percebida pelo autor como um quadro (que não é estático, mas sim está em constante processo) no qual ocorre a enunciação. Esse "quadro" carrega todos os elementos que compõem o discurso: as imagens, os posts, o jogo de cores, os links, os enunciadores e coenunciadores etc.

Os blogs instituem uma cena de enunciação específica, formada por uma cena englobante, que pode ser compreendida como o discurso intimista. Por ser um diário digital, no qual as pessoas escrevem sobre si mesmas, sobre suas vidas e suas ações cotidianas, diz-se que os blogs possuem um caráter intimista. A cena genérica do blog é o discurso diarístico. Este pressupõe que o escrevente fale sobre si, sobre sua vida cotidiana, seus anseios e desejos, registrando-os diariamante. A especificidade do blog é, no entanto, o fato de falar sobre si num ambiente público e coletivo, instituído pela internet.

A cenografia pressupõe uma cronografia (um momento de enunciação) e uma topografia (um lugar enunciativo). No blog, o momento da enunciação estende-se desde o instante de postagem da primeira mensagem até o momento em que os escreventes deixam de postá-las. O momento da enunciação corresponde, pois, a uma parte da adolescência. Já a topografia do blog é o hipertexto. Este determina o modo de enunciação interativo, ubíquo, inerente ao ambiente que se faz 
presente no blog. O hipertexto possibilita que a escrevente coloque em seu blog músicas, fotos, imagens animadas etc.

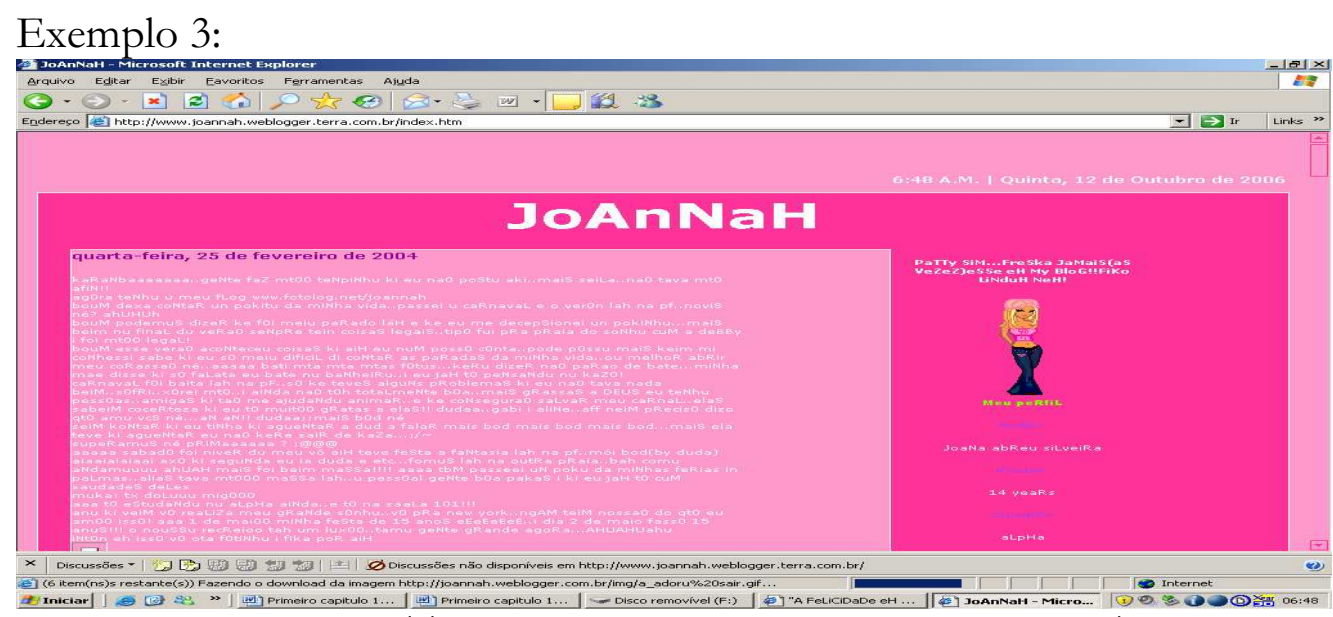

(Retirado de: http://www.joannah.weblogger.terra.com.br/index.htm)

"Patty sim, freska jamais (às vezes)." É com esta chamada que a escrevente do blog Joannah inicia a descrição de si mesma. Ao enunciar-se através desta frase, a escrevente pretende inicialmente dizer: eu sou isto, não aquilo. Porém, por que é necessário e importante para ela fazer essa restrição? Isso ocorre porque, possivelmente, os seus co-enunciadores são adolescentes da mesma faixa etária da escrevente (treze e quatorze anos), para os quais ser patty (ser "patricinha") é sinônimo de ser uma pessoa "cheia de não-me-toques", ou, nas palavras dos próprios adolescentes, ser uma pessoa "fresca". No intuito de quebrar essa imagem negativa que poderia ser atribuída a si própria, a escrevente enuncia: "sou patty, mas não sou freska só às vezes". Apenas observando esse trecho, nota-se a existência de um estereótipo inicial, indicado pela própria escrevente: o de ser "patricinha". O que é ser "patricinha"? Quais os estereótipos pré-atribuídos a elas?

As "patricinhas" são vistas como garotas que só usam roupas e acessórios de marca, que estão sempre seguindo as tendências ditadas pela moda televisiva, consideradas consumistas e fúteis por pensarem demais em bens materiais etc.

A formação discursiva da "patricinha" enquanto menina mimada e fútil circula, com certa facilidade, dentro do grupo do qual a 


\section{4}

adolescente faz parte. No entanto, não se pode concebê-la como uma unidade fechada em si mesma, mas sim como um fenômeno que representa sempre um embate entre posições ideológicas do sujeito social. Consoante Brandão (2004, p. 47): "constituindo o discurso um dos aspectos materiais de ideologia, pode-se afirmar que o discursivo é uma espécie pertencente ao gênero ideológico. Em outros termos, a formação ideológica tem necessariamente como um de seus componentes uma ou várias formações discursivas interligadas".

Assim, no momento da identificação que Joannah faz de si própria, ao afirmar que é "patricinha", são mobilizadas pelo interdiscurso todas as características estabelecidas pela formação discursiva corrente na sociedade em relação a essa representação. Isso se faz principalmente através do processo de estereotipização que guiará os co-enunciadores de Joannah no momento do estabelecimento de uma imagem da enunciadora. Antes de se discutir sobre a questão da estereotipização, cabe aqui uma breve abordagem teórica da noção de interdiscurso. Consoante Orlandi (2005, p.31), o interdiscurso pode ser definido como:

[...] aquilo que fala antes, em outro lugar, independentemente. $\mathrm{Ou}$ seja, é o que chamamos memória discursiva: o saber discursivo que torna possível todo $\theta$ dizer e que retorna sob a forma do preconstruído, o já-dito que está na base do dizível, sustentando cada tomada da palavra.

Desta forma, o já-dito decorrente da representação social da patricinha é acionado no fio do discurso presente no blog da Joannah, constituindo os sentidos da referida expressão.

Do mesmo modo, a noção de estereótipo é importante para se compreender a formação do ethos. Consoante Charaudeau e Maingueneau (2004, p. 213) os estereótipos podem ser concebidos como uma representação coletiva que subentende atitudes de indivíduos ou de grupos, direcionando seu comportamento. Assim, um estereótipo pode ser entendido, grosso modo, como um carimbo que é pré-atribuído a alguém. O estereótipo revela a forma como se pretende encaixar pessoas que possuam características semelhantes dentro de um mesmo esquema 
comportamental, como se essas pessoas não possuíssem vontade própria.

Amossy (2005b, p. 126), ao falar sobre a estereotipização no processo retórico, afirma:

O orador adapta sua apresentação de si aos esquemas coletivos que ele crê interiorizados e valorizados pelo seu público-alvo. Ele o faz não somente pelo que diz de sua própria pessoa (freqüentemente não é de bom tom falar de si), mas também pelas modalidades de sua enunciação. É então que ele incumbe o receptor de formar uma impressão do orador relacionando-o a uma categoria conhecida. (AMOSSY, 2005b, p. 126)

O esquema coletivo de representação da patricinha está de antemão interiorizado pelo seu público-alvo, pelo auditório particular da adolescente ou ainda pelos seus co-enunciadores. Para estes, esta imagem é bastante conhecida, e as características atribuídas a ela são comuns para todos, servindo como uma forma de classificação das garotas dentro de determinado esquema.

Desse modo, percebe-se como os estereótipos, colocados por Maingueneau na base do esquema do ethos, interferem na formação da imagem da fiadora e como o auditório ao qual o blog se dirige interfere no discurso da enunciadora. Assim, o ethos da enunciadora será construído a partir da interação constante entre enunciador e coenunciador, sendo o discurso da escrevente constantemente regulado pelas expectativas do auditório particular.

No caso do blog da Joannah, diz-se que o estereótipo inicial, que influencia a formação de um ethos pré-discursivo, é confirmado no ethos discursivo, quando ao ler os posts da escrevente, vêem-se os seguintes trechos/imagens:

(4) eu $i$ miNha MaMMy fomuS fazeR coNpRinhas nu $x 0 p i N$ beRamaR!!! (Postado em 15 de novembro de 2003)

(5) boJi demaNha paSSei a maNha toda No cabeLeREIro(coRta cabeLo, retoCaR aS luzes i piNta a uNha) iSSo eH bouMM!!!! (Postado em 13 de setembro de 2003) 
(6)

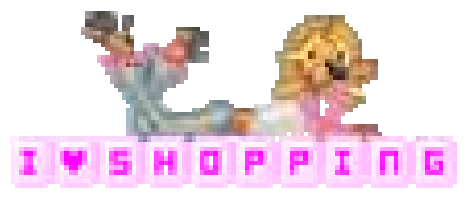

(7)

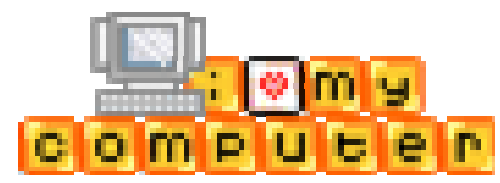

Em (4) a escrevente revela-se preocupada com a aparência, confirmando, então, o estereótipo inicial e reforçando a imagem formada a partir do ethos pré-discursivo. As imagens dos exemplos (6) e (7) também contribuem para a afirmação do estereótipo da "patricinha": no exemplo (6) a escrevente enuncia "I love shopping", no exemplo (7) "I love my computer", numa alusão ao consumismo, que também está presente no exemplo (5).

Também fica clara a interferência dos co-enunciadores no discurso da enunciadora e sua preocupação em ser "aceita" como patty dentro do seu grupo. Nos comentários feitos pelos co-enunciadores em relação às mensagens da enunciadora, destacam-se os seguintes trechos:

(8) teUb blogG táHh a tUa kRa heiNn pRima tDubHh rósiNha d patty...beinNn LiNdãOo bjüSS amadiNha!! Weblog : http://wWw.BbZiNhAaAh.wEbloggEr.cOm.bRaNa 'S - enviado em 15/11/2003 00:57:00 (Comentário do post de 11 de novembro de 2003)

Em (8) uma de suas co-enunciadoras afirma que o blog está a cara da Joannah, "bem rosinha, de patty”. Dessa forma, o próprio auditório particular atribui à enunciadora uma imagem de patricinha, mostrando a manutenção do estereótipo inicial formado no ethos pré-discursivo.

Além das características anteriores que contribuem para a formação do ethos, Maingueneau (2005b) destaca também a importância da análise de elementos como o tom, o fiador, a incorporação, para a correta compreensão deste conceito. 
Para Maingueneau (2005b), todo texto possui uma vocalidade que se manifesta no momento da enunciação. Essa vocalidade pode manifestar-se através do tom utilizado pelo enunciador no momento da enunciação efetiva. $\mathrm{O}$ tom ${ }^{8}$ permite, portanto, ao co-enunciador formar uma imagem do "corpo do enunciador", imagem esta que não corresponde a um corpo real, mas que faz surgir a figura de um fiador, aquele que enuncia através do discurso. $\mathrm{O}$ tom utilizado pela adolescente Joannah assemelha-se àquele utilizado pelas meninas adolescentes escreventes de blogs de forma geral: é um tom amoroso e afetuoso, caracterizado sobremaneira pela escolha de itens lexicais. Assim, o uso de palavras no diminutivo, a referência carinhosa (através de apelidos carinhosos) aos membros da família e aos amigos revelam claramente o tom da escrevente, o qual traz à tona a imagem de uma fiadora com tais e quais características, imagem com a qual o auditório particular tende a se envolver.

A análise deste blog deixa pistas para perceber qual seria a imagem pré-discursiva (ethos pré-discursivo) atribuída à Joannah e, ao mesmo tempo, revela que esta imagem pode ser confirmada no âmbito discursivo (ethos discursivo), uma vez que a própria enunciadora reivindica para si a imagem da "garota patty" e revela em seu discurso preocupações excessivas com a moda e com o consumismo, características atribuídas às patricinhas pela formação discursiva corrente em nossa sociedade.

Apesar de o blog ser um espaço público, no qual se revelam aspectos da vida cotidiana, não se pode afirmar que este seja o espaço do "escancaramento" da intimidade, já que os(as) blogueiros(as) escrevem aquilo que podem escrever, tendo consciência de que suas mensagens poderão ser lidas por qualquer pessoa, que estas poderão cair nas mãos do auditório universal. Isso pode ser comprovado ao analisarem-se os seguintes trechos:

(9) peRdi a coNfiaNsSa du me0 paPPy i da miNHa maMMy,eH podS agoRa eLeS tauM noRmaiS coMigu maiX aNteS eLeS tavauM beiNeStRaNhoS coMigo,tbM dep0iS do ke eu fiZ..nauM

\footnotetext{
${ }^{8} \mathrm{O}$ tom é revelado pelas escolhas lexicais feitas pelo enunciador. Ao falar de escolhas lexicais podese remeter à idéia saussuriana de paradigma.
} 
vo faLa oke poRq eH pRobLeMaS paRtikuLaReS, [...] (Postado em 25 de fevereiro de 2004)

(10) bouM esse veraOm acoNtecen coisas ki aHi eu nuM poss $\boldsymbol{O}$ cOnta [...] (Postado em 30 de novembro de 2003)

(11) não poSSo comeSSar a goStar deSSa peSSoa dinOvu... (Postado em 12 de dezembro de 2003)

Em (9), a adolescente mostra-se triste com a indiferença dos seus pais para com ela, no entanto seu discurso pressupõe que não pode revelar o motivo dessa indiferença no blog. Segundo Joannah, ela não pode falar ali o que a deixa triste, pois "eh problemas partikulares". O blog, então, não seria o espaço adequado para revelação dos problemas particulares. O mesmo acontece nos exemplos (10) quando a escrevente mantém em segredo as coisas que aconteceram naquele verão. Em (11), a escrevente diz que não pode voltar a "gostar daquela pessoa novamente", mas ainda assim, não revela quem é a pessoa pela qual ela resiste a se apaixonar novamente nesse trecho do blog. Assim, a adolescente adequa seu discurso ao auditório particular, mas o restringe na medida em que tem consciência de que sua mensagem pode "cair nas mãos" de pessoas indesejáveis.

A tese de que o blog representa uma espécie de "escancaramento" da intimidade é defendida por alguns estudiosos de hipertexto. Basanela (2003) afirma, em relação aos blogs, que:

Eles são diários abertos da vida, com fotos, experiências contadas abertamente por pessoas que na maioria das vezes se tornam anônimas na imensidão da internet; esses tipos de blog estão começando a criar uma nova cultura na sociedade, as pessoas passam a "espiar" a vida alheia da janela do seu computador." (BASANELA, 2003)

$\mathrm{Na}$ citação, a pesquisadora afirma ser o blog pessoal um espaço onde se pode contar tudo abertamente, o que não pode ser confirmado a partir da análise do blog da Joannah, como se pôde notar nos exemplos citados anteriormente, onde a dimensão do segredo e a idéia de que o blog pode ser lido por milhões de internautas continuam presentes nesse

\footnotetext{
${ }^{9}$ Retirado do site: http://www.iar.unicamp.br/disciplinas/am625_2003/Daniele_artigo.html, acesso em 02/08/2005 às 15:00hs.

HEINE - Considerações sobre a cena...
} 
diário digital. Assim, nos exemplos (9) a (11), pode-se perceber que a escrevente do blog não escancara sua intimidade no meio digital: seu discurso é marcado pela expectativa do auditório, pela tentativa de adaptação ao auditório particular e cortado pela possibilidade de que seus posts veiculados no blog possam cair nas mãos de pessoas indesejáveis. Assim, ela fala aquilo que pode ser dito no meio digital. Ela revela aquilo que pode ser revelado para que seja aceita dentro do seu grupo, sendo, portanto, seu discurso guiado e marcado pelas expectativas geradas pelos co-enunciadores.

A Análise do discurso tem mostrado que a presença da alteridade é própria e inerente a todos os processos de enunciação, não existindo um enunciado que seja desvinculado da influência "do outro". Os próprios diários tradicionais, apesar de serem escritos para se manterem em segredo, carregam também a dimensão da alteridade uma vez que suas mensagens destinam-se a um "outro" do discurso, derivado do desdobramento do "eu" enunciador. Vale lembrar, contudo, que os diários tradicionais não se destinavam a um auditório particular: eles eram escritos para se manterem em segredo e para não serem lidos. $\mathrm{O}$ diário tradicional dos adolescentes não era escrito com o objetivo de ser compartilhado com os amigos ou colegas de escola, o que vai diferenciálo do blog. $\mathrm{O}$ estudo dos gêneros digitais tem revelado inovações com relação a esse aspecto. Os blogs, que representam a transmutação dos diários tradicionais, revelam ainda mais fortemente a presença do "outro", uma vez que esse discurso é direcionado a um auditório particular para o qual o blogueiro destina suas mensagens. É esse auditório particular que interfere no discurso do escrevente, seja emitindo opiniões sobre os posts, comentando as mensagens postadas no blog ou direcionando o discurso dos escreventes a partir de suas expectativas e de estereótipos sociais. No blog, o "outro" leitor constituise ao mesmo tempo autor, uma vez que também é responsável pela construção do blog, fator que diferencia este último dos diários tradicionais. Neles, há o compartilhar de aspectos da vida pessoal e intimista que, nos diários tradicionais, eram mantidos em segredo e destinados a um outro desconhecido. Assim, o blog constitui-se como um espaço entre a esfera pública e privada, uma vez que permite que seus escreventes revelem aspectos de sua vida íntima direcionados a um 
auditório particular, mas podendo ser lidos pelo auditório universal, uma vez que o acesso aos blogs é livre e não pressupõe autorização prévia.

\section{CONSIDERAÇÕES FINAIS}

A concepção de ethos para a Análise do Discurso, postulada no esquema de Maingueneau (2005b), está relacionada a diversos elementos discursivos (tom, caráter e corporalidade, elementos constituintes da cenografia do discurso) e também aos estereótipos que circulam socialmente como categorias que influenciam na formação da imagem do enunciador.

Dessa forma, a categoria ethos não está ligada apenas ao enunciador, à imagem que este reivindica para si próprio, mas se apresenta como uma categoria interativa, uma vez que a imagem do enunciador adequa-se às expectativas de um auditório particular, que direciona e dirige o discurso do primeiro.

Assim, o blog, apesar de ser concebido como um espaço intimista, um diário virtual no qual se escreve sobre si, sobre sua vida pessoal, expectativas e sonhos, retomando a prática de escrita dos diários tradicionais, não representa o escancaramento da intimidade num meio público: a internet. Nos blogs, fala-se aquilo que pode ser dito, aquilo que atende às expectativas de um auditório particular que regula o discurso dos escreventes.

Pode-se dizer, portanto, que o blog instaura um novo espaço discursivo: o espaço intimista pautado na relação direta com o outro do discurso, no qual o "outro" ocupa na construção da intimidade do "eu" um lugar de destaque. O ethos vai, portanto, carregar a dimensão do "outro" discursivo, dos co-enunciadores, uma vez que a imagem do enunciador é criada e recriada por estes últimos, numa perspectiva interativa, através de processos de estereotipização, que podem ou não ser confirmados pelo processo discursivo.

A partir da análise dos objetos selecionados, percebeu-se que o blog não engendra um espaço discursivo no qual há a revelação da intimidade de forma completa, uma vez que a presença de um auditório 
particular, com suas expectativas, direciona o discurso dos escreventes, que dizem aquilo que pode ser dito e não 'escancaram' a sua intimidade.

Diante das questões colocadas aqui, pode-se afirmar que, na verdade, no blog, há a revelação de uma intimidade restrita, direcionada pelo olhar do outro, regulada pela possibilidade de os escritos irem parar nas mãos de pessoas desconhecidas, uma vez que a internet é um espaço público.

Diferentemente dos diários tradicionais, que eram escritos para que não fossem lidos pelo "outro", ou para que se mantivessem em esconderijos secretos, os blogs são escritos para serem lidos. As mensagens ali postadas destinam-se ao "outro" conhecido, pelo auditório particular ao qual os escreventes dirigem o seu discurso. Portanto, falar das práticas cotidianas e não propriamente "escancarar a intimidade" é a tônica desse gênero discursivo, que não pode ser considerado como a reedição do diário tradicional no meio digital.

\section{REFERÊNCIAS}

AMOSSY, R. Da noção retórica de ethos à análise do discurso. In: (Org.). Imagens de si no discurso: a construção do ethos. São Paulo: Contexto, 2005a. p. 9-16.

Estereotipagem e construção de uma imagem de si. In: (Org.).

Imagens de si no discurso: a construção do ethos. São Paulo: Contexto, 2005b. p. 125-127.

ARISTÓTELES. Retórica. Tradução e notas de Manuel Alexandre Júnior, Paulo Farmhouse Alberto e Abel do Nascimento Pena. Lisboa: Imprensa nacional; casa da moeda, 1998.

BASANELA, D. Internet : novos formatos na geração e disseminação de conteúdo. 2003. Disponível em:

<http://www.iar.unicamp.br/disciplinas/am625_2003/Daniele_artigo.html >.

BRANDÃO, H. H. N. Introdução à análise do discurso. São Paulo: Editora da Unicamp, 2004. 
CHARAUDEAU, P.; MAINGUENEAU, D. Dicionário de análise do discurso. Coordenação da tradução Fabiana Komesu. São Paulo: Contexto, 2004.

HEINE, P. V. B. O ethos e a intimidade regulada: especificidades da construção do ethos no processo de revelação da intimidade em blogs da Internet. Dissertação (Mestrado em Lingüística) - Universidade Federal da Bahia, 2007.

KOMESU, F. Entre o público e o privado: um jogo enunciativo na constituição do escrevente de blogs da Internet. 2005, 271p. Tese (Doutorado em Linguística) - Instituto de de Estudos da Linguagem, Universidade Estadual de Campinas, Campinas.

MAINGUENEAU, D. Discurso literário. Tradução de Adail Sobral. São Paulo: Contexto, 2006.

Gênese dos discursos. Tradução de Sírio Possenti. Curitiba: Criar Edições, 2005a.

Ethos, cenografia e incorporação. In: AMOSSY, R. Imagens de si no discurso: a construção do ethos. São Paulo: Contexto, 2005b. p. 68-92.

Análise de textos de comunicação. Tradução de Cecília P. de Souzae-Silva e Décio Rocha. São Paulo: Cortez, 2001.

Novas tendências em análise do discurso. Tradução de Freda Indursky. 3. ed. Campinas: Editora da UNICAMP, 1997.

MARCUSCHI, L. A. O hipertexto como um novo espaço da escrita em sala de aula. Recife, 2001. Artigo- Universidade Federal de Pernambuco. Mimeo.

MEYER, M. As bases da retórica. In: CARRILHO, M. M. (Org.). Retórica e comunicação. Tradução de Fernando Marinho. Lisboa: Edições Asa, 1994.

OLIVEIRA, R. Diários públicos, mundos privados: diário íntimo como gênero discursivo e suas transformações na contemporaneidade. Dissertação (Mestrado em Comunicação e Cultura Contemporâneas) - Univesidade Federal da Bahia, Faculdade de Comunicação, 2002.

ORLANDI, E. Análise de discurso: princípios e procedimentos. Campinas: Pontes, 2005.

ROHDEN, L. O poder da linguagem: a arte Retórica de Aristóteles. Porto Alegre: EDIPUCRS, 1997. 
SIBILIA, P. A intimidade escancarada na rede: blogs e webcams subvertem a oposição público versus privado. 2003. Disponível em: $<$ http://www.intercom.org.br/papers/congresso2003/pdf/2003_NP08_sibilia. pdf $>$.

Recebido em 13/08/07. Aprovado em 10/01/08.

\begin{abstract}
Title: Considerations about enunciatif scene: the construction of ethos on blogs
Author: Palmira Bahia Heine

Abstract: This article aims at discussing the construction of ethos on internet blogs. The research analyses two teenagers' blogs: Camila and Joana (16 and 14 years old, respectively). The analysis is based on principles of French Discourse Analysis and on Maingueneau (2005)'s view of ethos. Bearing in mind that the concept of ethos cannot be detached from rhetorical studies, the analysis also takes into account some conceptions pointed out by the field of Rhetoric. The article discusses how ethos is constructed in a public vehicle, the internet, within a private genre, the blog, bringing into focus the specificities and characteristics of ethos within this genre.
\end{abstract}

Keywords: ethos; blog; internet; discourse; teenagers.

Titre: Considérations sur la scène énonciative: la construction de l'éthos dans les blogs Auteur: Palmira Bahia Heine

Résumé: Cet article a l'intention de tisser quelques considérations sur la construction de l'éthos dans les blogs, dans l'Internet, ayant comme point de départ l'analyse de deux blogs d'adolescents: Camila et Joana (16 et 14 ans). On considère ici les présupposés théoriques de l'Analyse de Discours, bien que la conception de l'éthos postulée par Maingueneau (2005). On adopte aussi quelques notions postulées par la Rhétorique, une fois que le concept d'éthos ne peut être entièrement délié des études rhétoriques. On a l'intention, dans l'article, d'établir une discussion sur le moyen comment l'éthos est construit dans un véhicule publique (l'Internet), dans un genre discursif de caractère intimiste (le blog), à partir de la focalisation de spécificités et caractéristiques de l'éthos dans ce genre.

Mots-clés: éthos; blog; Internet; discourse; adolescent.

Título: Consideraciones sobre la escena enunciativa: la construcción del ethos en los blogs

Autor: Palmira Bahia Heine

Resumen: El artículo ora presentado pretende tejer algunas consideraciones acerca de la construcción del ethos en blogs, en la Internet, teniendo como punto de partida el análisis de dos blogs de adolescentes: Camila y Joana (de 16 y 14 años). Son considerados aquí los supuestos teóricos del Análisis del Discurso, bien como la concepción de ethos postulada por Maingueneau (2005). Son del mismo campo también algunas nociones postuladas por la Retórica, una vez que el concepto de ethos 


\section{4}

no puede estar totalmente desvinculado de los estudios retóricos. Se objetiva, en el artículo, establecer una discusión acerca del modo como el ethos es construido en un vehículo público (la Internet), dentro de un género discursivo de carácter intimista (el blog), a partir de la focalización de especificidades y características del ethos en ese género.

Palabras-clave: ethos; blog; Internet; discurso; adolescente. 